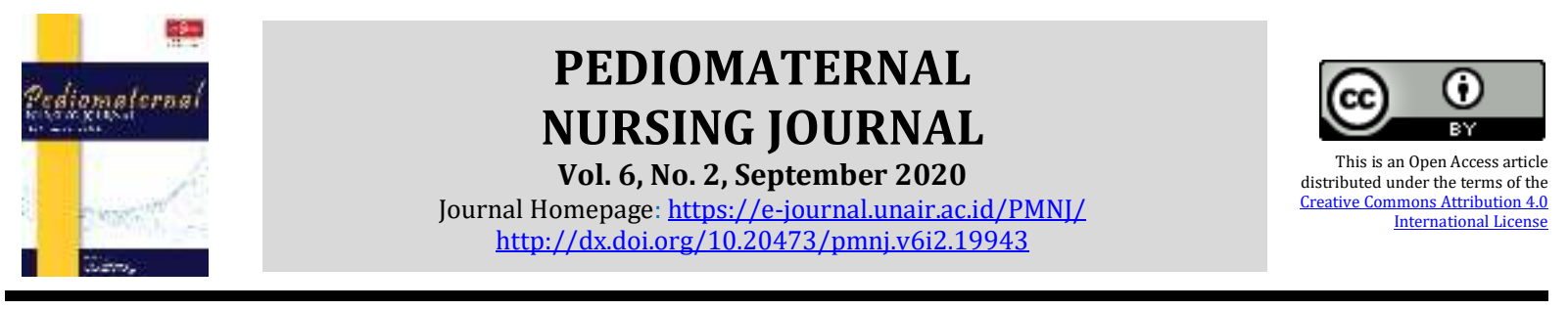

Original Research

\title{
The Correlation between Mothers' Breastfeeding Pattern and Stunting among Toddlers
}

\author{
Tiffatul Jannah Firdausya, Deisy Sri Hardini
}

Department of Nursing, Faculty of Health Sciences, Universitas Muhammadiyah Purwokerto, Indonesia

\section{ARTICLE HISTORY}

Received: June 16, 2020

Accepted: July 13, 2020

Published: Augustus 4, 2020

\section{KEYWORDS}

Breastfeeding; stunting; child; preschool;

malnutrition

\section{CORRESPONDING AUTHOR}

Tiffatul Jannah Firdausya jannahfird9@gmail.com Department of Nursing, Faculty of Health Sciences, Universitas Muhammadiyah Purwokerto, Indonesia

\begin{abstract}
Introduction: Stunting is a condition of the measured height of toddlers, which is less to the age. Stunting, which occurs in these children, is also considered in chronic nutrition problems. The study aimed to discover the correlation between breastfeeding mothers' pattern in breastfeeding for toddlers aged 0 days to 6 months with the stunting incidence in toddlers in Gandatapa village, Sumbang sub-district, Banyumas district.

Methods: This study implemented an observational analytic method that examined the correlation between breastfeeding mothers' patterns and stunting incidence. This research design was case control. This study conducted two sampling techniques; total sampling and simple random sampling, and each was used for sampling and control groups. The research sample collected 80 respondents. The study used a questionnaire of breastfeeding mothers and TB/U observation charts for ages 2 to 5 years, according to WHO 2005.
\end{abstract}

Results: Based on the bivariate analysis, the pattern of breastfeeding mothers in Gandatapa Village, Sumbang District, Banyumas Regency was in a bad category with 22 stunting toddlers (55\%). Pearson Chi-Square test on the Pattern of Breastfeeding Mothers towards Stunting Incidents in toddlers obtained $\mathrm{p}$-value $=0.024<0.05$ with an $\mathrm{OR}$ value of $2.852(95 \% \mathrm{CI}$ 1.137 - 7.152).

Conclusion: Toddlers under 24 to 35 months can increase the risk of stunting incidence when mothers have poor breastfeeding patterns.

Firdausya, T, J, \& Hardini, D, S. (2020). The Correlation between Mothers' Breastfeeding Pattern and Stunting among Toddlers. Pediomaternal Nurs. J., 6(2), 108-116. Doi: http://dx.doi.org/10.20473/pmnj.v6i2.19943

\section{INTRODUCTION}

Stunting (dwarf) is measured height condition of a toddler, which is less than the age. Stunting in infants occurs due to multifactors such as socioeconomic conditions, maternal nutritional intake during pregnancy, the incidence of illness in infants, and lack of nutritional intake during infancy. In the future, toddlers who experience stunting will have difficulty achieving physical and cognitive development. Stunting can also be defined as a toddler with z-score based on height for age less than 2SD/standard deviation (stunting) and less than -3SD (severely stunting) (Kemenkes, 2018).

Stunting can also be understood as a nutritional problem that can inhibit the physical and mental development of children. 
Besides, children are more vulnerable to infectious diseases. One of the factors which can be a risk of stunting incident in a toddler is the lack of nutritional intake of infants, especially the best nutritional intake for infants or ASI (breastmilk) (Millennium Challenge Account Indonesia, 2015).

RISKESDAS in 2018 divided breastfeeding into three categories: exclusive, predominant, and partial breastfeeding (Kemenkes. 2018). Exclusive breastfeeding means only giving breast milk to the baby for 6 months. The predominant breastfeeding is the mother breastfeeding her baby in 6 months but once was given with water, tea, or milk as prelacteal feeds or other water-based drinks. While partial breastfeeding is the mother breastfeeds her baby, the baby is also given extra food, either continuously given or as prelacteal feeds only (Pusat Data dan Informasi, 2014).

There are four causes of stunting, such as household and family characteristics, improper complementary feeding, improper breastfeeding, and infections. Several other factors affecting stunting are mother's age, Family Head occupation, mother's education, and family knowledge (Utami et al., 2019).

The World Health Organization, collecting data of stunting prevalence, discovered that Indonesia was considered as the 3rd country with the highest prevalence in The Southeast Asian region. The average prevalence of stunting toddlers in Indonesia in 2005 - 2017 was 36.4 percent (Kemenkes, 2018).

In Indonesia, around $30.8 \%$ or 7 million children under five experienced stunting. According to the provincial government, Central Java was 8th, which means that Central Java was included in 18 provinces with a high prevalence of stunting $30 \%$ $40 \%$ ). Based on a preliminary study conducted by the author, data from the Banyumas District Health Office, the highest number of stunting in Banyumas District was the Sumbang sub-district with the number of 449 stunting incidents to toddlers. (Dinas Kesehatan Kabupaten Banyumas, 2015).

Based on a preliminary study conducted in October 2019 at the Sumbang II health center, 40 infants aged 24 - 35 months were stunting. Based on interviews with midwives and public health center staff, many mothers in Sumbang District feed formula milk to the six months baby, and too early complementary feeding before six months could be a factor to the incidence of stunting in Sumbang sub-district.

The study aimed to determine the characteristics of respondents, reveal the pattern of mothers in breastfeeding toddlers, discover the classification of stunting in stunting toddlers and find out the correlation between patterns of breastfeeding mothers and stunting classification in toddlers in Gandatapa Village, Sumbang sub-district, Banyumas Regency.

\section{METHOD}

\subsection{Design}

A case-control study is a research design that involves how risk factors affect an incident using an observational-analytic method and a retrospective approach. This study implemented a case-control study design to examine the correlation between breastfeeding mothers' patterns and the incidence of stunting. The study aims to obtain data about a cause that exists in the past so that it becomes a current condition (Nasir and Muhith, 2011).

\subsection{Population, Samples, and Sampling}

The population is the entire object of the study (Notoatmodjo, 2010). Here, the population was mothers with children 24-35 months with z-scores (HAZ) -2 SD to $>-3$ SD in the stunting category and mothers with children 24-35 months with z- scores Score > -2SD up to 2 SD in the normal category in Gandatapa Village, Sumbang sub-district, Banyumas Regency September 2019 and obtained 123 toddlers.

The sample is a portion taken from the entire object of the research. (Notoatmodjo, 2010). The sample in this study was mothers with children 24-35 months in stunting and normal categories in Gandatapa Village, Sumbang sub-district, Banyumas Regency. A sample calculation was determined by looking at the number of stunting cases in toddlers 24-35 months in the Gandatapa village, and there were 40 toddlers experienced stunting. 40 out of 123 toddlers were in normal toddlers and included in the control group (normal) collected from 84 normal toddlers aged 24-35 months. 
Therefore, the total sample in this study was 80 respondents.

The sampling method in this study implemented a total sampling technique for the case group and a simple random sampling technique for the control group. Total sampling is a sampling technique where the sample number and the total population remain the same. Whereas, simple random sampling is a sample selected from a population done randomly with no considering the level in that population.

\subsection{Variables}

Variables are tendencies of the research focus. Variables indicate the feature of a group of people or objects in the research which have variations between one another (Riwidikdo, 2013). The independent variable is a variable that affects the appearance or change of the dependent variable (free) (Riwidikdo, 2013). Thus, the independent variable in this study was the pattern of mothers' breastfeeding. The dependent variable is a variable affected by an independent variable; in other words, this variable is the effect variable (bound) (Riwidikdo, 2013). The dependent variable in this study was the incidence of stunting in toddlers.

\subsection{Instruments}

The research instrument is all materials used to obtain, process, and interpret information from respondents by conducting the same measurement pattern (Nasir et al., 2011). The research instruments in this study consisted of demographic questionnaires, breastfeeding patterns, and stunting observation sheets.

\subsection{Procedure}

This research was conducted by data collection of primary data and secondary data. Primary Data is data collected by individuals or organizations directly through their objects (Notoatmodjo, 2010). This study collected primary data obtained directly from respondents, namely demographics of respondents, patterns of breastfeeding mothers, and measurement of nutritional status (using height-for-age WHO Growth Standard Curve) to stunting. Secondary data is data obtained indirectly, but obtained from archives and records. The secondary data was obtained from the Banyumas District Health Office, Public Health Center Sumbang, and Integrated Health Care Center Gandatapa.

In the process of collecting data, researchers conducted an ethical clearance process. After conducting an ethical clearance process and obtaining an ethical permit, the researcher continued to make and administer research-related permissions. After delivering the letter to Sumbang Public Health Center II and getting approval, the researcher began to carry out the research. In obtaining the data, the researcher came to the respondents' houses. The research procedures in this study were: 1) questionnaire distribution to Mother, 2) Respondents answering all questions, 3) for unclear or incomprehensible questions, respondents may ask about the question, 4) The researcher companions in filling out the questionnaire, and 5) After all answers collected, the researcher measured the stunting on the z-score observation sheet from WHO.

\subsection{Analysis}

After the data obtained, it was then coded with data processing software. After data coding obtained from the questionnaire, stunting scores were analyzed univariate and bivariate. Univariate analysis is used to analyze each variable by calculating the frequency distribution and proportions and discovering the respondent's identity, classification of stunting, and patterns of breastfeeding mothers.

Bivariate analysis was conducted to measure the level of correlation between two variables on an ordinal and nominal scale. Bivariate analysis in this study was ChiSquare (X2) correlation. Chi-square (X2) was used to find the correlation between the same two variables - Nominal or Ordinal scale, or in other words, the data used in the Chi-Square correlation test was categorical. Thus, the ordinal scale used was the pattern of breastfeeding mothers, and the nominal scale used was the stunting status variable.

\subsection{Ethical Clearance}

This research has passed the research ethics test and was declared to have passed the 
ethical test by the Health Research Ethics Commission of the University of Muhammadiyah Purwokerto. The registration number for the research ethics permit was KEPK/UMP/27/XI/2019.

\section{RESULT}

Table 1 illustrated that the control group and case group have the highest number in the age group of mothers between 21-35 years, 32 mothers (80\%), and 31 mothers $(77.5 \%)$. Most of the mothers worked as IRTs (Housewives) in both groups, 37 mothers $(92.5 \%)$ in the case group, and 36 mothers (90\%) in the control group. The most common occupation of the head of household (KK) is as laborers; 21 families (52.5\%) in the case group and 23 families (57.5\%) in the control group. The age of toddlers who experienced the most stunting was 27-29 months or 12 toddlers (30\%). The age of toddlers in the majority control group ranged from 27-29 months or 16 toddlers (40\%). Besides, the majority of the two respondent's under-five aged 24-26 months both in the case group and the control group were ten toddlers (25\%) and nine toddlers (22.5\%).

From the pattern table of breastfeeding mothers in Table 2, it was clear that the implementation of early breastfeeding initiation of mothers who had stunting and normal children conducted breastfeeding initiation $<1$ hour, i.e., or 27 respondents $(67.5 \%)$ and 37 respondents (92.5\%). In the implementation of exclusive breastfeeding, 25 mothers $(62.5 \%)$ from 40 mothers with stunting toddlers and willing to become respondents did not carry out exclusive breastfeeding. In contrast, the majority of toddlers or 24 toddlers $(60 \%)$ out of the total 40 toddlers in the control group received Exclusive breastfeeding.

The mother in the control group did breastfeeding $\geq$ eight times, which was more than the case group. In the control group, 32 respondents $(75 \%)$ breastfed $\geq$ eight times, while in the case group, 31 respondents $(77.5 \%)$ had breastfeeding frequency $\geq$ eight times. However, some mothers breastfed $<8$ times in case ( 9 mothers) and control group (8 mothers).

In this study, the categorization of stunting and severe stunting was carried out based on measurements of the Z-Score curve from WHO 2005 based on data from the measurement of the height of infants in each posyandu, which had been carried out by posyandu cadres. The study involved 40 stunting toddlers. The classification of stunting, according to Riskesdas (2018), is divided into 2; short (stunting) and very short (severe stunting).

In the case group, there were toddlers with short classification (stunting) of 30 toddlers (75\%) out of 40 toddlers in the case group. Toddlers are classified into short (stunting) category if TB/U z-score is in $\leq-2$ SD to - 3 SD. A total of 10 toddlers were in the very short category (severely stunting). Very short (severely stunted) was categorized by TB / U z-score is <- 3 SD.

Based on table 4, the correlation between the Pattern of Breastfeeding Mothers and Stunting incidents showed that Mothers with poor breastfeeding patterns and stunting toddlers were 22 respondents (55\%) higher than Mothers with poor breastfeeding patterns with normal toddlers was 12 respondents (30\%). Meanwhile, mothers with good breastfeeding patterns and stunting toddlers were 18 respondents (45\%) smaller than mothers with good breastfeeding patterns with normal toddlers was 28 respondents (17\%).

After tested with Pearson Chi-square on the Pattern of Breastfeeding Mothers against Stunting Incidents in infants, the results obtained p-value $=0.024<0.05$. It proved that there was a correlation between the pattern of breastfeeding mothers and the incidence of stunting in toddlers in Gandatapa village, Sumbang sub-district.

The odds ratio value in this study was $\mathrm{OR}$ $(95 \%$ CI $)=2.852$ (1.137 - 7.152), which proved that mothers with poor breastfeeding patterns obtained 2.852 times higher risk to toddlers stunting than mothers with good breastfeeding patterns.

\section{DISCUSSION}

\subsection{Respondents characteristics}

From 80 respondents, it obtained the results of age that most maternal during pregnancy was in the adult range from 21 to 35 years old. Pregnancy under 20 years old could cause many problems because it could affect 
Table 1. Frequency Distribution of Respondents Characteristics of Mother and Toddler

\begin{tabular}{|c|c|c|c|c|}
\hline \multirow{2}{*}{ Respondent Characteristic } & \multicolumn{2}{|c|}{ Stunting } & \multicolumn{2}{|c|}{ Normal } \\
\hline & $\mathbf{n}$ & $\%$ & $\mathbf{n}$ & $\%$ \\
\hline \multicolumn{5}{|l|}{ Mother's Age } \\
\hline$\leq 20$ years old & 6 & 15 & 4 & 10 \\
\hline 21 - 35 years old & 31 & 77.5 & 32 & 80 \\
\hline$>35$ years old & 3 & 7.5 & 4 & 10 \\
\hline \multicolumn{5}{|l|}{ Mother's Occupation } \\
\hline Housewife & 37 & 92.5 & 36 & 90.0 \\
\hline Labor & 2 & 5.0 & 2 & 5 \\
\hline Other & 2 & 2.5 & 2 & 5 \\
\hline \multicolumn{5}{|l|}{ Family Head Occupation } \\
\hline Labor & 21 & 52.5 & 23 & 57.5 \\
\hline Farmer & 1 & 2.5 & 4 & 10.0 \\
\hline Enterprise & 12 & 30.0 & 11 & 27.5 \\
\hline Other & 6 & 15.0 & 2 & 5.0 \\
\hline \multicolumn{5}{|l|}{ Age of Toddlers } \\
\hline $24-26$ months & 10 & 25.0 & 9 & 22.5 \\
\hline $27-29$ months & 12 & 30.0 & 16 & 40.0 \\
\hline $30-32$ months & 10 & 25.0 & 7 & 17.5 \\
\hline $33-35$ months & 8 & 20.0 & 8 & 20.0 \\
\hline \multicolumn{5}{|l|}{ Gender of Toddlers } \\
\hline Boy & 21 & 52.5 & 19 & 47.5 \\
\hline Girl & 19 & 47.5 & 21 & 52.5 \\
\hline
\end{tabular}

Table 2. Frequency Distribution of Mothers' Breastfeeding Pattern

\begin{tabular}{|c|c|c|c|c|}
\hline \multirow{2}{*}{ Respondent Characteristics } & \multicolumn{2}{|c|}{ Stunting } & \multicolumn{2}{|c|}{ Normal } \\
\hline & $\mathbf{n}$ & $\%$ & $\mathbf{n}$ & $\%$ \\
\hline \multicolumn{5}{|l|}{ Early Breastfeeding Initiation } \\
\hline Yes $(\leq$ an hour $)$ & 27 & 67.5 & 37 & 92.5 \\
\hline No ( $>$ an hour) & 13 & 32.5 & 3 & 7.5 \\
\hline \multicolumn{5}{|l|}{ Exclusive Breastfeeding } \\
\hline Yes & 15 & 37.5 & 24 & 60 \\
\hline No & 25 & 62.5 & 16 & 40 \\
\hline \multicolumn{5}{|l|}{ Mother's Breastfeeding Pattern } \\
\hline Good & 18 & 45.0 & 28 & 70 \\
\hline Poor & 22 & 55.0 & 12 & 30 \\
\hline \multicolumn{5}{|l|}{ Breastfeed eight times } \\
\hline$<$ Eight times & 9 & 22.5 & 8 & 25 \\
\hline$\geq$ Eight times & 31 & 77.5 & 32 & 75 \\
\hline
\end{tabular}

organs such as the uterus, even babies could be premature and underweight (Marmi, 2012). It was because a young pregnant woman cannot supply food adequately from her body to the fetus in her womb. Likewise, pregnancy for older ( $>35$ years) would cause anxiety about pregnancy and childbirth, and there was a decline in the function of several organs of the body so that it would affect fetal development (Prawirohardjo, 2012).

Respondent characteristics based on mother occupation in this study indicated that most of them were as a housewife (IRT)/ 37 mothers (92.5\%) in the case group and 36 mothers (90\%) in the control group. Whereas, mothers' occupation besides homemakers were two mothers $(5 \%)$ as laborers and two mothers $(2.5 \%)$ as others (self-employed, farmers, and entrepreneurs) in the case group. In the control group, two mothers (5\%) worked as laborers, and two mothers (5\%) others worked as others (selfemployed, farmers, and entrepreneurs). Based on the results of the analysis, toddlers who experienced stunting or not were more experienced in children with mothers who worked as housewives (IRT). It was in line with research conducted by Mentari (2018a, pp.1-5), which showed that stunting was more common in children with jobless mothers or homemakers. Even though the control group of mothers who worked as housewives with healthy babies also obtained a large proportion. So, it can be said that other factors also affected stunting. Although jobless mothers had more time to care for children, if care patterns provided 
Table 3. Stunting Classification in Toddler Stunting in Gandatapa Village, Sumbang sub-district in 2019

\begin{tabular}{lcc}
\hline Stunting Classification & n & \% \\
\hline Stunting & 30 & 75 \\
Severe Stunting & 10 & 25 \\
\hline
\end{tabular}

Table 4. The Relationship between The Patterns of Breastfeeding Mothers with Stunting Events

\begin{tabular}{lccccc}
\hline \multirow{2}{*}{ Mother's Breastfeeding Pattern } & \multicolumn{2}{c}{ The height-for-age status } & \multirow{2}{*}{ Total } & \multirow{2}{*}{ p } & \multirow{2}{*}{ OR } \\
\cline { 2 - 3 } & Stunting & Normal & & \\
\hline Poor & $22(55 \%)$ & $12(30 \%)$ & $34(42.5 \%)$ & & 2.852 \\
Good & $18(45 \%)$ & $28(70 \%)$ & $46(57.5 \%)$ & 0.024 & $(1.137-7.152)$ \\
Total & $40(100 \%)$ & $40(100 \%)$ & $80(100 \%)$ & & \\
\hline
\end{tabular}

were improper, then there would be nutritional problems (Mentari, 2018b).

Most of the occupations of the head of household were a laborer. Based on the interview results, most respondents answered that head of the family occupation was a freelance laborer. The results of this analysis were not in line with research conducted by Sulistyawati (2019), where a low family income would affect the quality and quantity of food consumed by the family. Food obtained from low-income household heads would usually be less varied and had little quantity, especially food for children. This limitation would increase the risk of nutritional problems. Meanwhile, in the results of the analysis of this study, the number of family heads who worked as laborers in the control group was more than the case group.

Toddlers 24-35 months had a 4.71 times higher opportunity of experiencing stunting compared with toddlers aged 0-5 months (Fenta et al., 2019). Age 12 - 35 months was the age which needed to give more attention to nutrition pattern because it was the crucial time to suffer from severely stunted (Tanaka et al., 2019). In this study, it could be considered that the toddlers were restricted to 24-35 months.

This study proved that most of the stunting toddlers occurred in males. This finding was in line with research conducted by Mugianti (2018) or 31 stunting toddlers; 21 males and 11 females. The male toddler had a strong and significant correlation to the incidence of stunting (Reurings et al., 2013). Gender is one of the direct factors in stunting (Mugianti, 2018b).

\subsection{Breastfeeding mothers' pattern}

This study revealed that the majority of respondents initiated early breastfeeding (IMD) in $<1$ hour. It was in line with Nadiyah (2014) research where breastfeeding initiation did not present significant differences in stunted children.

The patterns characteristics of breastfeeding mothers based on exclusive breastfeeding in this study indicated that exclusive breastfeeding in the case group was mostly not done. In the control group, the majority of respondents had performed exclusive breastfeeding for their children for six months without providing extra food or drinks besides breast milk. Giving exclusive breastfeeding was also related to colostrum administration. Majene discovered that the administration of colostrum had a significant correlation to the incidence of stunting (Yuliani, 2020). Colostrum was obtained from exclusive breastfeeding. Toddlers with no exclusive breastfeeding during the first six months had a greater risk of stunting (Arifin, 2012). Some mothers in this study said that their mothers taught respondents to give food to babies when they were 0 - 6 months old. Thus, family support could also affect the occurrence of stunting due to the failure of exclusive breastfeeding.

The characteristic patterns of breastfeeding mothers based on the frequency of everyday breastfeeding illustrated that most respondents had breastfed their children $\geq$ eight times per day or 31 respondents $(77.5 \%)$ and nine respondents $(22.5 \%)$ breastfeeding their children < eight times per day in the case group. In this study, the majority of respondents had breastfed their children more than eight times per day, which was in 
line with the recommendations of the Ministry of Health in 2008 both in the case group and in the control group.

This study means that both mothers gave breast milk for six months without providing extra drinks or food to the baby before the age of 6 months; in other words, it could be interpreted as a mother giving exclusive breastfeeding to her baby. The poor category meant that the mother still provided extra food or drinks than breast milk before the baby was six months old.

From the results of the analysis, it could be seen that toddlers who experienced stunting with poor breastfeeding patterns were 22 mothers (55\%) more than mothers with good breastfeeding patterns and not experience stunting was 12 mothers (30\%). These results were in line with research conducted by Ni'mah (2015), which indicated that 88.2 $\%$ toddler who does not get exclusive breastfeeding experienced stunting.

\subsection{Stunting classification}

Stunting, according to the Ministry of Health of the Republic of Indonesia (Kemenkes), was a toddler with z-score from height per age less than -2SD / standard deviation (TNP2K 2017). So in this study, toddlers can be classified in the short category (stunting) if the z-score height-for-age is in $\leq-2 \mathrm{SD}$. In the case group, there were toddlers with short classification (stunting) of 30 toddlers (75\%) out of 40 toddlers in the case group. Toddlers were in the very short (severely stunted) category if the z-score of the height-for-age growth chart was <- 3 SD. In this study, ten toddlers were in a very short class (severely stunting). Classification of stunting could worsen if there were no improvement from several stunting factors, or it could be said that poor and prolonged nutritional status could worsen the classification of stunting. Besides, some causes of stunting could affect the severity of the stunting classification if the cause was not immediately addressed or improved.

\subsection{Correlation between breastfeeding mother patterns and stunting incidents}

The reason for breastfeeding the baby until six months is that the milk's composition is sufficient for the growth and development of the baby if it is administered appropriately and correctly (Rukiyah, 2011). Infants less than six months do not have teeth, so they do not have enzymes that help crush food like an adult. This is why the baby is not administered for extra food than breast milk before he reaches the age of 6 months (Lim, 2012)

The result obtained by the pattern of breastfeeding mothers in Gandatapa Village, Sumbang sub-district, Banyumas Regency was in the poor category. This result was similar to the study done by Lestari (2018, pp. 123-127) in Surakarta, which showed that the incidences of stunting and inadequate breastfeeding have a significant correlation among children aged 24-59 months. After investigating the pattern of breastfeeding mothers in the poor category, it was still found that the mothers admitted that they still provided extra food or drinks such as porridge and formula milk to their babies before the age of 6 months so it could affect the growth and development of infants. In the manufacturing process, formula milk must be mixed with water, which is at risk of contamination (Lim, 2012). Small mistakes in preparing formula milk could be a source of illness in babies, such as diarrhea, which could cause babies to lose many fluids and could be fatal. The antibody element that protects the body from these bacteria entered the baby's body directly through breast milk. Immunity to disease was not found in babies who breastfeed with a bottle, so they were more at risk of disease than babies who were breastfed with milk (Lim, 2012). Infants with poor breastfeeding patterns during the first six months were at risk for stunting.

\section{CONCLUSION}

The mothers' pattern in breastfeeding their toddler from 0 to 6 months is in the unfavorable category in the case group. In contrast, in the normal group, the pattern of breastfeeding mothers is in a good category. It can be drawn that the pattern of breastfeeding mothers associated with stunting incidents in Gandatapa Village, Sumbang sub-district, Banyumas Regency is in the unfavorable category. Infants with poor breastfeeding patterns during the first 
six months were 2,582 times more at risk for stunting.

\section{ACKNOWLEDGEMENT}

The researcher would like to express gratitude for the support and assistance from the head of the Public Health Center Sumbang II, who had provided permission to the researchers to conduct a study in Gandatapa village. Furthermore, many thanks are also addressed to Gandatapa Village Midwife and Gandatapa Village Integrated health Care Center cadres, who assisted in the data collection process in this study. Thanks are also addressed to mentors, parents, siblings, and friends who have helped in this study.

\section{CONFLICT OF INTEREST}

The authors declare that there is no conflict of interest.

\section{REFERENCES}

Arifin, D. Z., Irdasari, S.Y., and Handyana, S. (2012) 'Analisis Sebaran dan Faktor Resiko Stunting pada Balita di Kabupaten Purwakarta', Unpad. Available at: http://pustaka.unpad.ac.id/archives/12 6746 (Accessed: 8 January 2020)

Dinas Kesehatan Kabupaten Banyumas. (2015) Profil Kesehatan Kabupaten Banyumas Tahun 2015. Banyumas : Dinas Kesehatan Kabupaten

Fenta, H. M., Workie, D. L., Zike, D. T., Taye, B. W., and Swain, P. K. (2019) "Determinants of Stunting among underfive Years Children in Ethiopia from the 2016 Ethiopia Demographic and Health Survey: Application of Ordinal Logistic Regression Model using Complex Sampling Designs". Clinical Epidemiology and Global Health, 8(2), pp. 404 - 413 [online]. Available at: https://doi.org/10.1016/j.cegh.2019.09 .011 (Accessed: 2 June 2020)

Kementerian Kesehatan RI. (2010) Riset Kesehatan Dasar Tahun 2010. E-book [online] Available at: http://kesga.kemkes.go.id/images/ped oman/Riskesdas\%202010\%20Nasional. pdf (Accessed: 14 January 2020)
Kementerian Kesehatan RI. (2018) Buletin Jendela Data dan Informasi Kesehatan Topik Utama: Situasi Balita Pendek (Stunting) di Indonesia. E-book [online]. Available at: www.kemkes.go.id , download > Buletin-Stunting-2018 (Accessed: 14 January 2020)

Kementerian Kesehatan RI. (2018) Riset Kesehatan Dasar Tahun 2018. E-book [online]. Available at: http://kesmas.kemkes.go.id/assets/upl oad/dir_519d41d8cd98f00/files/Hasilriskesdas-2018_1274.pdf (Accessed: 18 November 2019)

Lestari ED, Hasanah F, and Nugroho NA. (2018) 'Correlation between nonexclusive breastfeeding and low birth weight to stunting in children'. Pediatrica Indonesia, 58(3), pp. 123-127.

Lim, Robin. (2012) ASI Eksklusif Dong! Buku untuk para Ayah oleh Ibu Robin Lim. Bali: Yayasan Bumi Sehat.

Marmi and Rahardjo, K. (2012) Asuhan Neonatus, Bayi, Balita, dan anak pra sekolah. Yogyakarta: Pustaka Pelajar

Mentari, Suharmianti and Hermansyah, Agus. (2018) Faktor - faktor yang berhubungan dengan status stunting anak usia 24 - 59 bulan di Wilayah Kerja UPK Puskesmas Siantan Hulu. Pontianak Nutrition Journal, 1(1), pp.1-5 [online]. DOI:

https://doi.org/10.30602/pnj.v1i1.275

Millenium Challenge Account Indonesia. (2015) Stunting dan Masa Depan Indonesia. E-book [online]. Available at: http://mca-indonesia.go.id/wpcontent/uploads/2015/01/Background er-Stunting-ID.pdf (Accessed: 20 September 2019)

Mugianti, S., Mulyadi, A., Anam, A., and Najah, Z. (2018)' Faktor Penyebab Anak Stunting Usia 25-60 Bulan di Kecamatan Sukorejo Kota Blitar'. Jurnal Ners dan Kebidanan (Journal of Ners and Midwifery), 5(3), pp. 268-278. doi: https://doi.org/10.26699/jnk.v5i3.ART. p268-278

Nadiyah. (2014) 'Faktor Resiko Stunting pada Anak usia 0 - 23 bulan di Provinsi Bali, 
Jawa Barat, dan Nusa Tenggara Timur'. Jurnal Gizi dan Pangan, 9 (2), pp. 125 132.

Nasir, M. A dan Ideputri. (2011) Metodologi Penelitian Kesehatan. Yogyakarta: Mulia Medika

Ni' mah, Khoirun and Nadhiroh, Siti R. (2015) 'Faktor yang Berhubungan dengan Kejadian Stunting pada Balita'. Media Gizi Indonesia, 10 (1), pp. 13 - 19 http://dx.doi.org/10.20473/mgi.v10i1. 13-19

Notoatmodjo, Soekidjo. (2010) Metodologi Penelitian Kesehatan. Jakarta : Rineka Cipta

Prawirohardjo, S. (2012) Ilmu Kebidanan. Jakarta : P.T Bina Pustaka Sarwono Prawirohardjo

Pusat Data dan Informasi (PUSDATIN). (2014) 'Infodatin Pusat Data dan Informasi Kementerian Republik Indonesia: Situasi dan Analisis ASI Eksklusif'. E-book [online]. Available at: https://www.kemkes.go.id/resources/d ownload/pusdatin/infodatin/infodatinasi.pdf (Accessed: 12 September 2019)

Reurings, M., Vossenaar, M., Doak, C. M., and Solomons, N. W. (2013) 'Stunting rates in infants and toddlers born in metropolitan Quetzaltenango, Guatemala'. Nutrition, 29(4), [online]. Avaliable at: https://doi.org/10.1016/j.nut.2012.12. 012

Rukiyah, A Y. (2011) Asuhan Kebidanan III Nifas. Jakarta: Trans Info Media

Sulistiyawati, A. (2019). Faktor - faktor yang berhubungan dengan kejadian stunting pada balita, Jurnal Ilmu Kebidanan, 5 (1),

Tanaka, J., Yoshizawa, K., Hirayama, K., Karama, M., Wanjihia, V., Changoma, M.
S., and Kaneko, S. (2019) 'Relationship between dietary patterns and stunting in preschool children: a cohort analysis from Kwale, Kenya'. Public Health, 173, pp. 58-68 [online]. Available at: https://pubmed.ncbi.nlm.nih.gov/3125 4679/

Tim Nasional Percepatan Penanggulangan Kemiskinan. (2017) '100 KABUPATEN/KOTA PRIORITAS UNTUK INTERVENSI ANAK KERDIL (STUNTING)'. E-book [online]. Available at:

http://www.tnp2k.go.id/images/uploa ds/downloads/Binder_Volume1.pdf (Accessed: 12 September 2019)

United Nations Children's Fund (UNICEF), World Health Organization, International Bank for Reconstruction and Development/The World Bank. (2019) 'Levels and trends in child malnutrition: key findings of the 2019 Edition of the Joint Child Malnutrition Estimates'. E-book [online]. Available at: https://www.who.int/nutgrowthdb/jm e-2019-key-findings.pdf?ua=1

(Accessed: 12 September 2019).

Utami, Ressa A ; Setiawan, Agus; \& Fitriyani, Poppy. (2019). Identifying causal risk factors for stunting in children under five years of age in South Jakarta, Indonesia. Enferma Clinica 29(2), pp. 606-611. https://doi.org/10.1016/j.enfcli.2019.0 4.093

Yuliani, Eva ; Muzakkir ; Yunding, Junaedi ; Indrawati ; Irwan, Muhammad ; Immawanti ; \& Djalal, Muspirah. (2020). Age to start eating fish is a determinant factor of stunting in children age 25-60 months in Majene Regency, 2018. Enfermeria Clinica 30(2), pp. 466 - 469 [online]. https://doi.org/10.1016/j.enfcli.2019.0 7.139 